ADAM ŚWIEŻYŃSKI

\title{
Sprawozdanie z konferencji naukowej „W poszukiwaniu przyrodniczego, filozoficznego i teologicznego obrazu Wszechświata", Instytut Filozofii UKSW w Warszawie, 15.05.2021 r.
}

\begin{abstract}
Streszczenie. 15 maja 2021 roku odbyła się konferencja naukowa W poszukiwaniu przyrodniczego, filozoficznego i teologicznego obrazu Wszechświata, zorganizowana przez Instytut Filozofii Uniwersytetu Kardynała Stefana Wyszyńskiego w Warszawie. Okazją do zorganizowania konferencji była przypadająca 17 maja 2021 roku pierwsza rocznica śmierci ks. dr. hab. Grzegorza Bugajaka (1966-2020), wieloletniego pracownika Instytutu Filozofii UKSW i jego dyrektora w latach 2016-2020 oraz sekretarza redakcji czasopisma filozoficznego Studia Philosophiae Christianae w latach 1997-2020, redagowanego w Instytucie Filozofii UKSW. W konferencji, oprócz zaproszonych prelegentów, wzięli udział pracownicy Instytutu Filozofii UKSW oraz przedstawiciele innych ośrodków naukowych, a także przyjaciele i znajomi ks. Grzegorza Bugajaka.
\end{abstract}

Słowa kluczowe: Grzegorz Bugajak; nauki przyrodnicze; filozofia; teologia

15 maja 2021 roku odbyła się konferencja naukowa $W$ poszukiwaniu przyrodniczego, filozoficznego i teologicznego obrazu Wszechświata, zorganizowana przez Instytut Filozofii Uniwersytetu Kardynała Stefana Wyszyńskiego w Warszawie. Konferencja, z powodu obostrzeń sanitarnych, związanych z trwającą pandemią wirusa SARS-CoV-2, została przeprowadzona w trybie on-line. Okazją do zorganizowania konferencji była przypadająca 17 maja 2021 roku pierwsza rocznica śmierci ks. dr. hab. Grzegorza Bugajaka (1966-2020), wieloletniego pracownika Instytutu Filozofii UKSW i jego dyrektora w latach 2016-2020 oraz sekretarza redakcji czasopisma filozoficznego Studia Philosophiae Christianae w latach 1997-2020, redagowanego w Instytucie Filozofii UKSW. W konferencji, oprócz zaproszonych prelegentów, wzięli udział pracownicy Instytutu Filozofii UKSW oraz przedstawiciele innych ośrodków naukowych, a także przyjaciele i znajomi ks. Grzegorza Bugajaka. 
Na początku konferencji dr hab. Adam Świeżyński zaprezentował materiał wspomnieniowy dotyczący osoby i działalności śp. ks. Grzegorza Bugajaka. Znalazły się w nim m.in. materiały dźwiękowe z nagraniami muzycznymi z udziałem Grzegorza Bugajaka z okresu działalności zespołu muzycznego Hebron, do którego należał podczas studiów w Wyższym Seminarium Duchownym w Łodzi. Następnie prof. dr hab. Anna Latawiec omówiła działalność naukową i organizacyjną ks. Bugajaka oraz zaprezentowała osobiste wspomnienia o Zmarłym, z którym współpracowała przez ponad dwadzieścia lat. Kolejnym elementem wprowadzającym w konferencję było odtworzenie nagrania wideo $\mathrm{z}$ ostatniego publicznego wystąpienia naukowego ks. dr. hab. Grzegorza Bugajaka, które miało miejsce podczas 11. Polskiego Zjazdu Filozoficznego w Lublinie, w czasie dyskusji panelowej pt. Naturalizm - nadnaturalizm, w dniu 13 września 2019 roku ${ }^{1}$. Ks. Bugajak przedstawił wówczas swoje stanowisko w kwestii relacji między naturalizmem i nadnaturalizmem, opowiadając się za monizmem metafizycznym oraz uznając tradycyjne przeciwstawienia dualistyczne za sytuację analogiczną do biblijnego sposobu oznaczania krańców pewnego zbioru (całości rzeczy), np. biblijne „niebo i ziemia” z Ksiegi Rodzaju.

W dalszej części konferencji zaprezentowano dziesięć wystąpień tematycznych, które zostały podzielone na trzy części. Po nich odbyła się także dyskusja dotycząca zaprezentowanych referatów.

W części pierwszej, zatytułowanej Wokót fllozofii ks. Grzegorza Bugajaka, prof. dr hab. Anna Lemańska w wystąpieniu Ks. Grzegorz Bugajak. W poszukiwaniu przyrodniczego, flozoficznego i teologicznego obrazu Wszechświata przedstawiła sylwetkę naukową, główne poglądy filozoficzne oraz dorobek naukowy ks. Bugajaka, na który złożyło się wiele interesujących publikacji, koncentrujących się wokół problemów z zakresu filozofii przyrody, filozofii nauk przyrodniczych i relacji

1 Wystąpienie jest dostępne na stronie: https://zjazdfilozoficzny.kul.pl/panele-dyskusyjne; [dostęp 2021/08/04]. 
między naukami przyrodniczymi a teologią. $\mathrm{W}$ opinii prelegentki prace te stanowią znaczny wkład w rozwój filozofii. Ponadto autorka wystąpienia zwróciła uwagę na to, że badania Grzegorza Bugajaka dotyczące relacji nauka - religia są obecnie szczególnie ważne i mogą pomóc przezwyciężyć szereg nieporozumień, które narosły wokół tego problemu. Współcześnie zdolność patrzenia na problemy z różnych punktów widzenia jest dla filozofa bardzo cenna, gdyż wiedza o świecie „poszatkowana” na poszczególne dyscypliny naukowe przestaje być przydatna w tworzeniu całościowej wizji rzeczywistości, a to właśnie należy uznać za jedno z głównych zadań filozofa.

Następnie dr Michał Latawiec (Instytut Filozofii UKSW w Warszawie) zaprezentował stworzoną przez Grzegorza Bugajaka systematyzację pojęcia przypadku oraz jej aplikację do zagadnień związanych z ochroną przyrody (Ü̇yteczność koncepcji przypadku Grzegorza Bugajaka w naukach przyrodniczych). W swoim wystąpieniu podkreślił, że w uporządkowanym świecie pojawiają się i takie zdarzenia, których wystąpienie ma charakter przypadkowy. $Z$ tej racji zastosowanie filozoficznej koncepcji przypadku, wypracowanej przez Grzegorza Bugajaka i przewidzianej przez niego do analizy treści teorii naukowych oraz klasyfikacji zdarzeń przypadkowych, może okazać się użyteczne w obszarze ochrony środowiska. Autor zaprezentował treść propozycji Bugajaka, a następnie omówił okoliczności pojawiania się w przyrodzie zjawisk przypadkowych, rodzących dylematy poznawcze u przyrodników. Swoje analizy zilustrował konkretnymi przykładami. W rezultacie wskazał na te sposoby interpretacji przypadku z koncepcji Bugajaka, które, zdaniem prelegenta, mogą okazać się szczególnie przydatne w pracach ekologów.

Dr hab. Piotr Bylica (Instytut Filozofii Uniwersytetu Zielonogórskiego) w swoim wystąpieniu (C.S. Lewisa argument z pragnień przeciwko naturalizmowi. Na marginesie rozważań ks. Grzegorza Bugajaka o naturalizmie) przedstawił różne sformułowania argumentu z pragnień - wysuniętego przeciwko naturalizmowi - autorstwa Clive'a S. Lewisa. Analizie poddał zarzuty o brak logicznej 
poprawności jego wywodu oraz dotyczące zwodniczego charakteru czynników irracjonalnych, do jakich zaliczają się uczucia i pragnienia. Wykazał, że sformułowania, w których mamy do czynienia z brakiem konkluzywności antynaturalistycznego wniosku Lewisa, można jednak traktować jako poznawczo wartościowe, gdyż są one oparte na indukcyjnym schemacie wnioskowania. Istnieją natomiast sformułowania, które jedynie wielkim kosztem, jakim jest uznanie Wszechświata za absurdalny, można uznać za niekonkluzywne. Zatem, zdaniem autora, podejrzenie, iż odwołanie do czynników irracjonalnych osłabia argumentację Lewisa, okazuje się błędne.

Druga część konferencji, zatytułowana Wokót filozofii i nauk przyrodniczych, rozpoczęła się od wystąpienia dr. hab. Radosława Kazibuta (Wydział Filozoficzny Uniwersytetu im Adam Mickiewicza w Poznaniu), który w swoim referacie (Filozofia przyrody w alchemii. Zarys zwiqzków) przedstawił związki pomiędzy dociekaniami filozofów przyrody a rozwojem tradycji alchemicznej. Odwołał się do wybranych koncepcji, ukształtowanych w dziejach alchemii. Autor argumentował na rzecz tezy, że dociekania alchemików przybierały postać rozbudowanych systemów tworzących koherentne obrazy świata przyrody, które implikowały określone typy filozofii przyrody.

Z kolei ks. dr hab. Janusz Mączka (Wydział Filozoficzny Uniwersytetu Papieskiego Jana Pawła II w Krakowie) w swoim referacie (Filozofia w kontekście nauki. Stare problemy w nowym wydaniu) podjął zagadnienie relacji między filozofią a naukami przyrodniczymi. Jego zdaniem można te relacje uznać za interakcję, którą określił jako współprzenikanie obu tych dziedzin wiedzy. To współoddziaływanie filozofii z nauką podobne jest do niedomykającego się koła. Trudno jest owo wspólprzenikanie jednoznacznie scharakteryzować, ale można wskazać pewne idee towarzyszące mu. Po pierwsze uświadomienie sobie filozoficznego uwikłania teorii naukowej powoduje często rozszerzenie jej rozumienia oraz ujawnia, jak wiele informacji na temat głębokiej struktury świata zawartych jest $\mathrm{w}$ teorii naukowej. Sformułowanie „filozofia w nauce” można by uznać za 
charakterystyczne dla współczesnego ujmowania związku filozofii z naukami przyrodniczymi. Należy pamiętać, że wspólna droga filozofii i nauk przyrodniczych pozwala osiągać interesujące poznawczo wyniki, ważne dla rozumienia świata zewnętrznego. Po drugie wspólprzenikanie się filozofii z naukami przyrodniczymi jest procesem dynamicznym i twórczym. Zarówno filozofia, jak i nauka, ulegają ciągłym zmianom, które w istotny sposób wpływają na rozwijanie się procesu współprzenikania. Trudno jest przewidywać, w którą stronę proces ten będzie ewoluował. Ważne jest jednak, wskazał autor wystąpienia, aby w tym twórczym procesie dostrzec, że największym sukcesem nauk empirycznych, trwającym do dziś, jest coraz lepsze ugruntowanie się przekonania, że Wszechświat stopniowo, choć tylko w przybliżeniu, ujawnia nam tajemnice swojej struktury.

Ostatnim prelegentem w tej części konferencji była dr hab. Janina Buczkowska (Instytutu Filozofii UKSW w Warszawie), która w swoim wystąpieniu przedstawiła realizm strukturalny jako stanowisko reprezentujące ten nurt myślowy w dyskusji prowadzonej wokół realizmu naukowego oraz jego wybranych zalet i słabości (Realizm strukturalny a problem reprezentacji w nauce w kontekście sporu o realizm naukowy). Autorka uznała, że realizm strukturalny jest odpowiedzią na wyzwanie, jakie realizmowi naukowemu stawiają historyczne fakty zmiany teorii w nauce. Realizm strukturalny nawiązuje do semantycznego ujęcia teorii naukowych i wypracowanego w tym podejściu aparatu pojęciowego. Zgodnie $\mathrm{z}$ realizmem strukturalnym to, co zostaje zachowane $z$ dojrzałych teorii naukowych po zmianie teorii, to ich sformułowania matematyczne, będące abstrakcyjnymi modelami teorii. Są one aproksymacyjnie prawdziwe, gdyż reprezentują realne struktury rzeczywistości w sposób wolny od ontologicznej interpretacji, narzuconej przez język teorii. Realizm strukturalny i nawiązujący do niego semirealizm, który rozszerza niezmienniczość dojrzałych teorii na własności detekcyjne obiektów fizycznych, bronią tezy realizmu naukowego w kwestii aproksymacyjnej prawdziwości teorii naukowych, interpretując realistycznie 
zmiany teorii naukowych. Pozostawiają jednak na boku istotny dla realizmu problem reprezentowania rzeczywistości w teoriach naukowych. Oba wspomniane stanowiska, zdaniem J. Buczkowskiej, nawiązując do modelowego ujęcia teorii naukowych, przyjmują, że reprezentacja jest izomorfizmem struktur matematycznego modelu teorii i rzeczywistości. Takie rozumienie reprezentacji, w opinii autorki wystąpienia, jest zbyt wąskie, bo nie uwzględnia tego, że struktura zjawisk nie jest jednoznacznie określona. Strukturę tę dla teorii zastępuje matematyczny model danych, który odzwierciedla zjawiska przedstawione jako związki własności określonych przez teorię. Realistyczna interpretacja modelu danych stanowi dla realizmu strukturalnego konieczne uzupełnienie, aby spełniał on naczelną tezę realizmu, głoszącą, że nauka poznaje świat taki, jaki jest niezależnie od teorii. Stanowi to podstawę, aby broniona w realizmie strukturalnym aproksymacyjna prawdziwość teorii naukowych miała ugruntowane uzasadnienie. W referacie zostały więc przedstawione podstawowe elementy współczesnej dyskusji wokół realizmu naukowego oraz stanowiska realizmu strukturalnego i semirealizmu jako uzgodnienie realizmu naukowego $\mathrm{z}$ faktem radykalnej zmiany teorii. Autorka pokazała konsekwencje, jakie dla realizmu strukturalnego wynikają z semantycznego (modelowego) ujęcia teorii naukowych i związanego $\mathrm{z}$ tym pojęcia reprezentacji jako izomorfizmu struktur. W ostatnim fragmencie wystąpienia wykazała, że aby spełnić postulaty realizmu naukowego, zarówno realizm strukturalny, jak i semirealizm powinny być uzupełnione o interpretację reprezentacji rzeczywistości w modelu danych w duchu realizmu naukowego.

Trzecia część konferencji, nazwana Varia philosophica, zawierała cztery wystąpienia dotyczące rozmaitych zagadnień filozoficznych, także związanych z problematyką, którą podejmowal śp. ks. Grzegorz Bugajak. Dr hab. Dariusz Piętka (Instytut Filozofii UKSW w Warszawie) w swoim referacie (Dwie możliwe interpretacje paradoksu Zenona z Elei „Korzec prosa”) zaprezentował autorską interpretację paradoksu Zenona z Elei. Prelegent zwrócił uwagę, że w przypadku 
wspomnianego paradoksu wszystkie zachowane argumenty Zenona znane są z przekazów filozofów późniejszych. „Korzec prosa” jest zdawkowo przedstawiony przez Arystotelesa w Fizyce oraz znajduje się w Komentarzu do „Fizyki” Arystotelesa autorstwa Simplikiosa. Obydwa fragmenty, które stanowiły przedmiot rozważań autora wystąpienia, zawierają częściowo odmienną terminologię. Występują w nich rozumowania oparte na innych schematach wnioskowania. Celem zaprezentowanych analiz było uzasadnienie, że fragment z Fizyki Arystotelesa może sytuować omawiany paradoks jako argument przeciw ruchowi, a nie jako argument przeciw wielości, jak przedstawia się go zazwyczaj w świetle przekazu Simplikiosa.

W kolejnym wystąieniu (Znaczenie, recepcja i konsekwencje flozoficzne encykliki "Aeterni Patris" w kontekście pytania ofilozofie chrześcijańska) ks. bp. dr hab. Jacek Grzybowski (Instytut Filozofii UKSW w Warszawie) przedstawił treść i znaczenie dokumentu papieskiego, który stał się inspiracją do odnowienia badań filozoficznych nad spuścizną Tomasza z Akwinu. J. Grzybowski zauważył, że dziewiętnaste stulecie to jeden $\mathrm{z}$ najbogatszych $\mathrm{w}$ wydarzenia i treści okresów historii myśli ludzkiej. Jeśli popatrzymy na ten czas nie tylko pod kątem wydarzeń o znaczeniu ideowym, to uzmysłowimy sobie, że symbolicznie otwiera je wielka rewolucja francuska (1789), a kończy wybuch I wojny światowej (1914). Naukowe teorie i filozoficzne przesłania, jakie zrodziły się w tym okresie - kantyzm, heglizm, materializm, marksizm, społeczny i biologiczny ewolucjonizm, pozytywizm, radykalny ateizm - były szeroko propagowane na uniwersytetach, a także w gabinetach politycznych i w izbach parlamentów. Nie wszyscy żyjący wówczas intelektualiści zdawali sobie sprawę z przemożnej siły filozoficznych nowinek czy przełomowego znaczenia ideowych propozycji. Tylko uważny namysł nad tym, co wtedy dokonywało się w europejskiej myśli, co działo się w kulturze, nauce, historii, filozofii i religii, pozwalał zauważyć, że nadchodzą bardzo poważne zmiany. Jedną z kluczowych postaci, która dostrzegła moc filozoficznych idei, rozbrzmiewających w dyskusjach tego 
stulecia, był włoski duchowny Gioacchino Vincenzo Raphaelo Luigi Pecci, późniejszy papież Leon XIII. Właśnie ten papież, świadomy wagi i mocy ideowych skutków nowych prądów pod koniec XIX wieku, w bardzo trudnych dla Kościoła katolickiego czasach, we wrogiej chrześcijaństwu światopoglądowej atmosferze, spowodowanej wpływem idealistycznych filozofii i fascynacją rodzącym się marksizmem, ogłosił w 1879 roku encyklikę Aeterni Patris. Papież wskazywał sposoby intelektualnego wspomagania i odbudowywania znaczenia teologii i religii w życiu społecznym, zachwianego przez nurty postoświeceniowe i modernistyczne. Leon XIII przekonywał, że jeśli misją Kościoła jest nauczanie, to jest on odpowiedzialny także za ocenę treści, jakie pojawiają się w życiu społecznym i politycznym. Narody, państwa i wspólnoty nie żyją jedynie sprawami ekonomicznymi czy bytowymi, ale przede wszystkim tym, co dokonuje się w kulturze, sztuce, filozofii. Papież niemal proroczo dostrzegł także, jak wiele zależy od filozofii. Zdaniem prelegenta, w świetle wciąż powracającego pytania o zasadność i potrzebę filozofii chrześcijańskiej, warto spojrzeć retrospektywnie na znaczenie wspomnianej encykliki i zawartej w niej wizji roli filozofii w ludzkim poszukiwaniu odpowiedzi na pytania, wynikające $\mathrm{z}$ aktualnego postępu cywilizacyjnego, naukowego i kulturowego.

Następny referat (Czego teologia może nauczyć się od mechaniki kwantowej?) wygłosił ks. dr hab. Wojciech P. Grygiel (Wydział Filozoficzny Uniwersytetu Papieskiego Jana Pawła II w Krakowie). Autor zaproponowal, aby spojrzeć na obraz rzeczywistości materialnej, proponowany przez mechanikę kwantową, przez pryzmat wybranych problemów teologicznych, dotyczących interakcji Boga z przyrodą. Zdaniem prelegenta pomimo wielu żmudnych prób pogodzenia obrazów świata kształtowanych w teologii i w naukach szczegółowych, wspólny grunt, na którym te dwa obszary intelektualnych dociekań mogłyby się zbiegać, nie został jeszcze w pełni zidentyfikowany. Wykorzystując tzw. teologię ewolucyjną jako nowe i unikalne ramy, w której nauki i teologia są rzeczywiście doprowadzone do spójnego 
zestrojenia, można uznać, że ustalenia z zakresu mechaniki kwantowej rzucają nowe światło na proponowane modele dotyczące współdziałania Boga i przyrody. Według W. Grygiela teologia nie może dłużej prowadzić dialogu z nauką, lecz raczej powinna przyjąć naukę i jej metodę jako własną podstawę konceptualną. Takie podejście skutecznie likwiduje napięcia, jakie mogą powstawać między tymi dwoma obszarami badań i tworzy solidny grunt, na którym ani teologia ani nauka nie zmieniają się w ideologię. Ponadto umożliwia prowadzenie dialogu ze współczesnym ateizmem naukowym na solidnych podstawach i przywraca wiarygodność teologii w aktualnej kulturze sekularystycznej.

Ostatnim prelegentem był ks. prof. dr hab. Jan Krokos (Instytut Filozofii UKSW w Warszawie), który w swoim wystąpieniu (Od mórwienia do dyskusji) zaprezentowal „mówienie”, ,rozmowę”, „dialog” $\mathrm{i}$ „dyskusję" jako cztery bliskoznaczne terminy i cztery fenomeny ze sobą spokrewnione. Zdaniem J. Krokosa mówienie to sensowne artykułowanie dźwięków przez podmiot osobowy i jako takie jest warunkiem pozostałych aktywności. Rozmowa jest wzajemnym mówieniem do siebie przynajmniej dwóch osób na jakiś temat. Dialog i dyskusja, będące rozmową osób, różnią się przedmiotem, celem i strukturą. Dla obu rozmowa jest fundamentem. Warunkiem dialogu i dyskusji jest wewnętrzna wolność osób, które w nich biorą udział. Głównym celem dialogu jest zapoznanie się ze stanowiskiem i poglądami jego uczestników na określony temat. Uczestnicy dialogu nie muszą posiadać równych kompetencji. Dyskusja jest dialogiem sformalizowanym, kwalifikowanym. Jej celem jest rozwiązanie jakiegoś problemu. W dyskusji musi być zatem wyraźnie określony jej przedmiot, aspekt oraz muszą zostać uzgodnione pojęcia. Dyskutanci muszą posiadać podobne kompetencje w dyskutowanych sprawach. Dyskusja posiada też swą wewnętrzną, logiczną strukturę.

Konferencja została zakończona dyskusją nad zaprezentowanymi referatami, a także osobistymi nawiązaniami niektórych uczestników do ich spotkań i kontaktów ze śp. ks. Grzegorzem Bugajakiem. 
Dr hab. Adam Świeżyński przypomniał o numerze czasopisma Studia Philosophiae Christianae (4/2020), który został poświęcony pamięci ks. Bugajaka oraz zapowiedział, że w tłumaczonej na język angielski Powszechnej Encyklopedii Filozofii (wydawca: Polskie Towarzystwo Tomasza z Akwinu) zostanie umieszczone hasło poświęcone osobie zmarłego filozofa.

\title{
REPORT ON THE CONFERENCE "IN SEARCH OF A SCIENTIFIC, PHILOSOPHICAL AND THEOLOGICAL IMAGE OF THE UNIVERSE", INSTITUTE OF PHILOSOPHY CSWU IN WARSAW, MAY 15, 2021
}

\begin{abstract}
On May 15, 2021, the conference In Search of a Scientific, Philosophical and Theological Image of the Universe was held, organized by the Institute of Philosophy of the Cardinal Stefan Wyszyński University in Warsaw. The occasion to organize the conference was the first anniversary of the death of Fr. Prof. Grzegorz Bugajak (1966-2020), a long-time employee of the UKSW Institute of Philosophy and its director in 2016-2020 and the secretary of the editorial office of the philosophical journal Studia Philosophiae Christianae (1997-2020), edited at the Institute of Philosophy of the Cardinal Stefan Wyszyński University in Warsaw. In addition to the invited speakers, the conference was attended by members of the UKSW Institute of Philosophy and representatives of other research centers and friends and acquaintances of Fr. Grzegorz Bugajak.
\end{abstract}

Keywords: Grzegorz Bugajak; natural sciences; philosophy; theology

\footnotetext{
ADAM ŚWIEŻYŃSKI

Uniwersytet Kardynała Stefana Wyszyńskiego w Warszawie, Instytut Filozofii

(Cardinal Stefan Wyszyński University in Warsaw, Institute of Philosophy)

ORCID https://orcid.org/0000-0003-0430-4530

a.swiezynski@uksw.edu.pl

DOI 10.21697/spch.2021.57.S.01

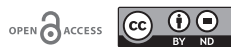

Tekst jest udostępniany na zasadach licencji Creative Commons (CC BY-ND 4.0 Międzynarodowe). Zgłoszono: 07/08/2021. Zrecenzowano: 29/08/2021. Zaakceptowano do publikacji: 11/09/2021.
} 